\title{
Regulation of Coal Polymer Degradation by Fungi
}

\author{
Quarterly Report \\ July 1 - September 30, 1997
}

Work Performed Under Contract No.: DE-FG22-94PC94209

\author{
For \\ U.S. Department of Energy \\ Office of Fossil Energy \\ Federal Energy Technology Center \\ P.O. Box 880 \\ Morgantown, West Virginia 26507-0880 \\ By \\ University of Notre Dame \\ Department of Civil Engineering and \\ Geological Sciences \\ Notre Dame, Indiana 46556
}




\section{Disclaimer}

This report was prepared as an account of work sponsored by an agency of the United States Government. Neither the United States Government nor any agency thereof, nor any of their employees, makes any warranty, express or implied, or assumes any legal liability or responsibility for the accuracy, completeness, or usefulness of any information, apparatus, product, or process disclosed, or represents that its use would not infringe privately owned rights. Reference herein to any specific commercial product, process, or service by trade

name, trademark, manufacturer, or otherwise does not necessarily constitute or imply its endorsement, recommendation, or favoring by the United States Government or any agency thereof. The views and opinions of authors expressed herein do not necessarily state or reflect those of the United States Government or any agency thereof. 


\begin{abstract}
During this reporting period we have further studied the oxidation of soluble coal macromolecules by lignin peroxidase from Phanerochaete chrysosporium. Previous studies by others have suggested that a soluble fraction (coal macromolecule B-III) from a nitric acid solubilized North Dakota Lignite is depolymerized by this enzyme. Our investigations indicate that fraction B-III is a substrate for lignin peroxidase as this material is decolorized in the presence of lignin peroxidase $\mathrm{H} 8$ and hydrogen peroxide. Of interest, however, is the observation that little, if any, depolymerization of this material occurs. Instead, it appears that lignin peroxidase and coal macromolecule B-III form a precipitate. These results are similar to those observed in our investigations of lignin peroxidase mediated oxidation of oxalate solubilize coal macromolecule. Previous studies in our laboratory using a spectrophotometric assay suggested that, in addition to oxalate, several other fungal metabolites are able to solubilize leonardite. We have reinvestigated this phenomenon using a more reliable gravimetric procedure for assessing solubilization. Our results confirm our earlier findings that malate, oxaloacetate and citrate are effective solubilizing agents whereas succinate, fumarate and $\alpha$-ketoglutarate solubilize relatively small amounts of leonardite. Finally, we have studied the composition of the insoluble material remaining following extensive solubilization by sodium oxalate. The ratio of hydrogen to carbon is increased in the insoluble material relative to the parent leonardite. However, the ratio of oxygen to carbon is also increased in the insoluble material. Thus, the insoluble material does not appear to be more highly reduced that the parent leonardite and is not likely to be a better fuel that the parent material.
\end{abstract}




\section{Introduction}

The overall objective of our research is to gain a better understanding of the manner in which wood rotting fungi degrade low rank coal. In some low rank coal, divalent cations form ionic bonds which link individual coal macromolecules (1). These linkages are broken by metal chelators and the relatively polar coal macromolecules are soluble in water. Oxalate ion is secreted by a variety of fungi and substantial evidence indicates that this compound is important in vivo for solubilization of some low rank coals. In addition to oxalate, however, fungi secrete a variety of metal chelators. Interestingly, a number of Krebs cycle intermediates also chelate metal ions and some of these compounds are over expressed in certain fungi for commercial production of these compounds. For example Aspergillus niger is able to convert 80$85 \%$ of its initial carbon source to citric acid (2). During this reporting period we assessed the ability of Krebs Cycle intermediates to solubilize leonardite.

Solubilization presumably makes coal macromolecules more available for subsequent attack by degradative enzymes. Wondrak et al. (1) have shown that water soluble coal macromolecule from a nitric oxide oxidized North Dakota Lignite is a competitive inhibitor of lignin peroxidase from Phanerochaete chrysosporium and have presented evidence that the coal macromolecule is partially depolymerized by this family of enzymes. We have reinvestigated this possibility.

Although there is considerable interest in solubilized coal macromolecule, the residual insoluble material is also of interest as substantial amounts of this material would likely remain in fungal and biomimetic solubilization processes. Thus, during this reporting period we have further examined the nature of this material. 


\section{Results}

The ability of several Krebs Cycle intermediates to solubilize leonardite is presented in Table 1. In a previous quarterly report, using a spectrophotometric assay, we showed that some of these intermediates could, indeed, partially solubilize this low rank coal. In the present study, a more precise gravimetric procedure was used to confirm our initial observations. Specifically we showed that malate, oxaloacetate and citrate were effective in solubilizing leonardite. These results are significant because they demonstrate that any microorganism that can over express and secrete these intermediates can also solubilize leonardite.

\section{Table I.}

\section{Solubilization of Leonardite by Krebs Cycle Intermediates}

\section{Kreb Cycle Intermediate}

Malate
Fumarate
$\alpha-$ Ketoglutarate
Oxaloacetate
Succinate
Citrate
Isocitrate

\section{Percent Solubilization}

$$
\begin{array}{r}
34 \% \\
4 \% \\
9.5 \% \\
38.5 \% \\
7 \% \\
44 \% \\
40.5 \%
\end{array}
$$

Solutions (75 mM) of Krebs Cycle intermediates in water were prepared from the free acid or their sodium salts. The $\mathrm{pH}$ of each solution was then adjusted to $\mathrm{pH} 7$ with $\mathrm{HCl}$ or $\mathrm{NaOH}$. The ability of each compound to solubilize leonardite was then determined as follows. To each of three $20 \mathrm{~mL}$ scintillation vials was added $20 \mathrm{mg}$ of leonardite and $10 \mathrm{~mL}$ of one of the Krebs Cycle intermediate solutions. These mixtures were agitated for twenty four hours after which time the mass of the insoluble material was determined gravimetrically. The amount of material solubilized was then calculated by difference.

In a previous quarterly report we showed that, even after extensive treatment with sodium oxalate, a substantial amount $(\sim 40 \%)$ of leonardite was refractory to solubilization. It would be logical to suggest that the refractory material might represent a more "mature" fraction of the coal, i.e., a fraction that might resemble a bituminous coal. If this is true, such a fraction would be expected to be more highly reduced than the parent leonardite. The elemental analysis of leonardite and the insoluble material remaining after extraction of leonardite by sodium oxalate solution is presented in Table 2 and shows that the ratio of hydrogen to carbon is increased in the extracted 
sample relative to the parent leonardite. However, the ratio of oxygen to carbon is also increased. Thus, the insoluble material remaining after extraction with sodium oxalate does not appear to be more highly reduced and is probably not a better fuel than than the parent leonardite.

Table II.

\section{Elemental Analysis of Leonardite and the Insoluble Residue that Remains Following Extensive Extraction of Leonardite with Sodium Oxalate Solution.}

$\begin{array}{lrr}\text { Analyte } & \text { Leonardite } & \text { Residue } \\ & & \\ \text { Carbon } & 48.60 \% & 40.46 \% \\ \text { Hydrogen } & 3.31 \% & 3.90 \% \\ \text { Nitrogen } & 1.03 \% & 0.60 \% \\ \text { Sulfur } & 2.11 \% & 0.64 \% \\ \text { Oxygen } & 23.73 \% & 24.68 \% \\ \text { Ash } & 21.22 \% & 29.71 \%\end{array}$

A major interest of our research centers on the role of fungal oxidative enzymes in the biodegradation of low rank coal. Research to date suggests that such enzymes have little or no role in solubilization of low rank coal. There is, however, some evidence that indicates that soluble coal macromolecules are substrates for lignin peroxidases and that these enzymes may function to depolymerize soluble coal macromolecules (3). In previous quarterly reports we showed that oxalate solubilized coal macromolecule was an excellent competitive inhibitor of lignin peroxidase mediated veratryl alcohol oxidation and that this coal macromolecule was probably a good inhibitor because it was a good substrate. However, we did not find any evidence that would suggest that substantial depolymerization of the macromolecule occurred. To further investigate the role of lignin peroxidase in solubilization of low rank coal macromolecule we obtained a sample of the nitric acid oxidized North Dakota Lignite used by Wondrak et al. (3). This material was a generous gift from Dr. Willis Wood. Soluble coal macromolecule designated as fraction B-III by these authors was prepared as described (3) and the ability of this material to serve as a substrate for lignin peroxidase was assessed used two different enzyme assays. In the first, we showed that lignin peroxidase H8 was 
able to mediate partial decolorization of this material (Figure 1). In the second assay, depolymerization was monitored by gel permeation high performance liquid chromatography (Data not shown). Although disappearance of the parent material was

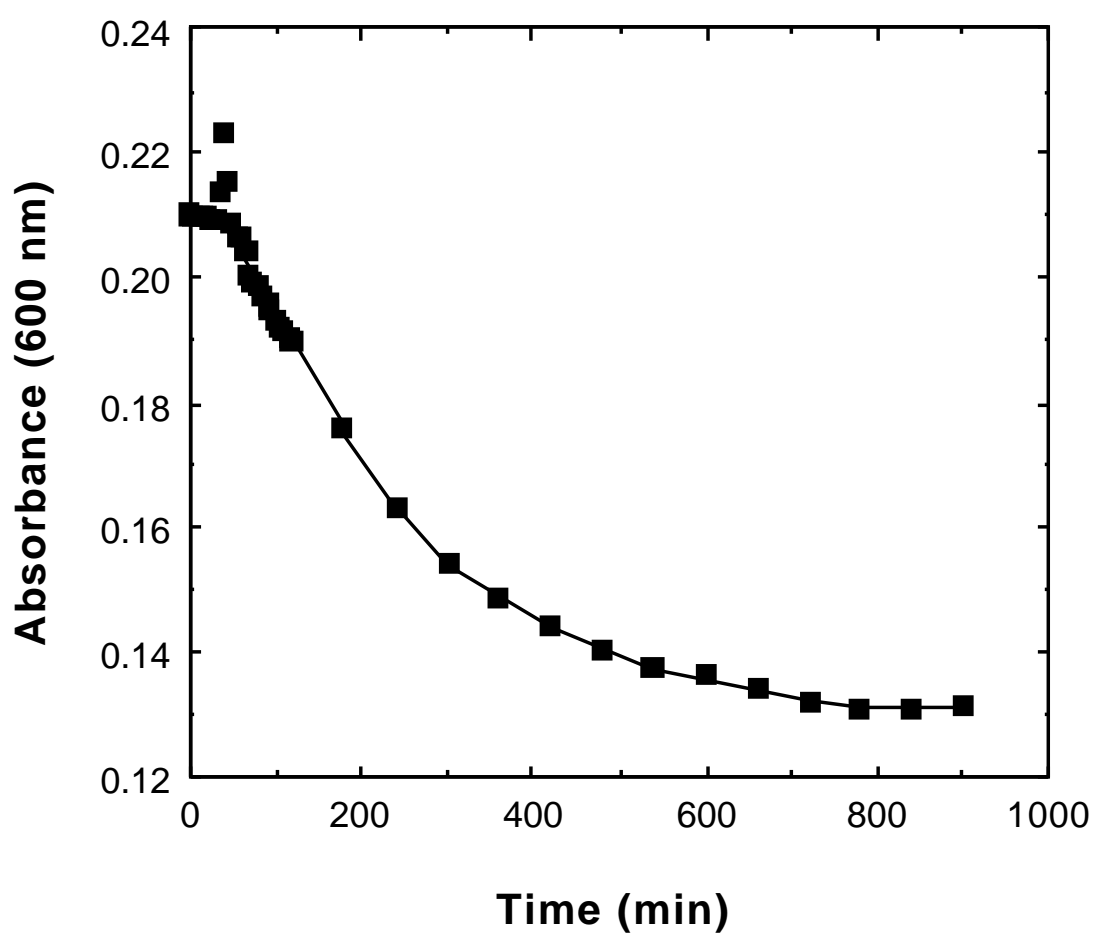

Figure 1. Decolorization of Coal macromolecule B-III by lignin peroxidase $\mathrm{H} 8$ from Phanerochaete chrysosporium The reaction mixture contained $116 \mathrm{nM}$ lignin peroxidase $\mathrm{H} 8,100 \mu \mathrm{g}$ coal macromolecule B-III, $1.5 \mathrm{mM}$ veratryl alcohol and $1.0 \mathrm{mM}$ hydrogen peroxide in $220 \mathrm{mM}$ sodium tartrate buffer, $\mathrm{pH} 4.5$, in a total volume of $1.0 \mathrm{~mL}$. Reactions were initiated by the addition of hydrogen peroxide and monitored at $600 \mathrm{~nm}$ at room temperature. In control incubations in which hydrogen peroxide and/or enzyme was omitted, no decolorization was observed.

observed, we could not detect the formation of lower molecular weight products. Furthermore, we showed that, lignin peroxidase formed a precipitate with part of the BIII mixture that likely accounts for the disappearance of parent material that was observed. Thus lignin peroxidases can mediate oxidation of water soluble coal macromolecule resulting in bleaching of chromophores in this material. However, depolymerization of coal macromolecule does not appear to be a major function of lignin peroxidases. 


\section{References}

1) Faison, B.D. (1993) The chemistry of low rank coal and its relationship to the biochemical mechanisms of coal solubilization. In: Microbial transformations of low rank coal. (Ed. D.L. Crawford) CRC Press, Boca Raton 223 p.

2) Kiel, H., R. Gurvin and Y. Henis (1981) Citric acid fermentation by Aspergillis niger on low-sugar concentrations and cotton waste. Appl. Env. Micrbiol. 42(1):1-4.

3) Wondrak, L., Szanto, M. and W.A. Wood (1989) Depolymerization of water soluble coal polymers from subbituminous coal and lignite by lignin peroxidase. Appl. Biochem. Biotechnol.20/21:765. 